\title{
Determinants of Catfish Entrepreneurship in Imo State Nigeria
}

\author{
Osuji M.N, Anyanwu U.G, Oshaji I, Onyemuwa S.C. \\ Department of Agricultural Economics, Federal University of Technology Owerri
}

\begin{abstract}
This study aimed to analyze catfish entrepreneurship in Imo State with specific objectives to identify the socio-economic characteristics of catfish entrepreneurs, estimate the cost and returns of catfish entrepreneurs and factors influencing their returns, Multi-stage random sampling technique was used to select 120 fish farmers. Primary data was collected with the aid of well-structured questionnaire. The data obtained was analyzed using descriptive statistical technique, cost and return model, multiple regression analysis, The result of the descriptive statistical technique showed that $37.50 \%$ of the cat fish entrepreneur's fall within the age bracket of 35-45years and mean age was 43 years, 58.33\% of the cat fish entrepreneurs are men while only $41.67 \%$ of them are women, 50\% of cat fish entrepreneurs have attended primary education, $40 \%$ of the cat fish entrepreneurs have between 2- 5 persons in their households and the mean household size was 7 persons. The result of the cost and return showed that total variable cost was estimated as $\$ 2573041.25$ which is about $73.32 \%$ of the total cost. The total fixed cost was 1937226.58 which is $26.70 \%$ of the total cost incurred. The total cost was 3510267.83 and the total revenue was 4673521.25 .
\end{abstract}

Keywords: Catfish entrepreneurship, Determinants, Imo state

\section{Introduction}

The world fish production was at 97.2 million toones (live weight) an estimated value of 16 billion USD. The production of farmed food fish (finfish, crustaceans, molluscs and other aquatic animals) was at 70.2 million toones (FAO, 2015). China is the major producer and ranks number one in top ten countries of the world, it expanded its fish export from 6.0 percent to $35.1 \mathrm{~kg}$ (FAO, 2012). Nigeria ranks first in Africa with more than 2 million people involved in fisheries and aquaculture, followed by morocco and Uganda. Despite this statistics, developing countries consumption has increased geometrically owing to steady demand and declining fish production. Fish consumption is based on locally and seasonal availability with supply driving the chain. Though it is the most traded food commodity worldwide sustaining its production and encouraging its diversification owing to malnourishment and food insecurity in the face of a global population burst becomes the most efficient way of safeguarding our future. The fish food chain serves as a good potential for the provision of health, wealth and employment, as it provides employment to large number of people who are involved in boat building and maintenance, fish marketing and research.

Nigeria is a country that is agriculture based where the greatest percentage of the population depend on farming as major occupation and contributes about $1 / 3$ of the Gross Domestic Product (GDP) of the Nation (Amao et al, 2009).The contribution of the fishery sub-sector to GDP at 2001 current factor cost increased from N76.76 billion to N162.61 billion in 2005 (CBN Report, 2005). Fish is a significant source of protein to the large teaming population of Nigeria. Fish is an important source of animal protein in the country. Adekoya (2004) reports that fish products provides as much as $60 \%$ of protein in humans. A large population of Nigerians are fish consumers with a demand estimated at about 1.4million metric tons per annum. Amiengheme (2005) also enumerated that apart from human consumption, fish is important for animal feed, a source of raw materials for allied industries and a source of employment for many Nigerians (Esu et al, 2009).Unfortunately, Nigeria is not producing enough fish for consumption, therefore, fish production is not meeting the countries domestic demand and the fish industry is not providing the much needed financial empowerment that fish farmers need. According to FAO (2006a), fish supply in Nigeria amounts to 400,000 tons of supply in comparison to the 800,000 tons of demand. Nigeria is one of the highest importers of fish in subsahara africa bringing in some 600,000 metric tonnes (MT) annually (Hempel, 2010). The increase demand of fish is due to its low caloric value, minute starch content, high in protein, low in fat, quick to prepare and has a delicious tastes. The demand - supply gap of fish in the country is worrisome and Nigeria is said to be the highest importer of fish among the developing countries with records indicating an average of 560,000 tons annually (Presidential Forum, 2005). The problem of demand- supply gap can be addressed through entrepreneurship, defined by Wiklund (1998) as "taking advantage of opportunity by novel combination of resources in ways which have impact on the market. Cole (2005) defines entrepreneurship as the purposeful activity an individual or a group of associated individuals undertake in order to initiate, maintain, or earn profit by production and distribution of economic goods and services. 


\section{Materials and Methods}

Imo State is located in the South-Eastern area of Nigeria and it is bordered by Abia State on the East, by the River Niger and Delta State on the West and Rivers State to the South. This study was conducted in Southeast Nigeria, which is located between latitudes $4^{0} 10^{1} \mathrm{~N}$ and $7^{0} 8^{1} \mathrm{~N}$ and longitudes $5^{0} 30^{1} \mathrm{E}$ and $9^{0} 27^{1} \mathrm{E}$. The population of the zone is $32,952,778$ or $22.46 \%$ of the total population of Nigeria (NPC, 2006). The principal food crops are yam, cassava, cocoyam and maize while the cash crops are cocoa, oil palm, groundnuts, rubber and cotton (Okoye, 2010; Osuji et al. 2012).Multi-stage sampling technique was used to select households from which socioeconomic characteristics, cost and revenue, fish production, processing and marketing is carried out in the study area. In the first stage one agricultural zone was randomly selected from the three agricultural zones that make up Imo state. In the second stage, two local government areas were randomly from the selected agricultural zone. In the third stage two communities were selected from the two LGA, in the fourth stage one village was randomly selected from each of the two communities making a total of four villages for the study. In the final stage thirty (30) fish farmers were chosen from the list of registered farmers with the assistance of community resident extension agent making a total of one hundred and twenty (120) fish farmers.

The study utilised primary data which was collected by use of structured questionnaire and interview schedule, while the secondary information were gotten from journals and textbooks.

Objective 1, 2 and 3 were analysed using simple descriptive statistics e.g means and percentages, cost-returns model and Multiple Regression Function.

The multiple regression model for objective 3 is given as follows:

$\mathrm{Y}=\mathrm{f}\left(\mathrm{X}_{1}, \mathrm{X}_{2}, \mathrm{X}_{3}, \mathrm{X}_{4}, \mathrm{X}_{5} . \mathrm{X}_{6}, \mathrm{X} 7, \mathrm{X}_{8}, \mathrm{X}_{9}, \mathrm{X}_{10}\right)$

Where, $Y=$ Net return $(\AA), X_{1}=$ Farm size (hectare), $X_{2}=$ Cost of labour ( $\$ X_{3}=$ Household size, $X_{4}=$ Farming experience (years), $X_{5}=$ Education (years), $X_{6}=$ Other input $\operatorname{cost}(\AA), X_{7}=$ Fixed cost $(\aleph)$ (depreciated value of asset, interest charged), $\mathrm{X}_{8}=$ Cost of feed ( $) \mathrm{X}_{9}=$ Marital Status (married $=1$, otherwise $=0$ ) , $\mathrm{X}_{10}=$ Gender (male $=1$, female $=0$

\section{Results and Discussion}

Distribution of catfish entrepreneurs according to their socioeconomic characteristics

\begin{tabular}{|l|l|}
\hline Socioeconomic variables & Mean distribution \\
\hline Age & 43 years \\
\hline Household size & 7 persons \\
\hline Years of experience & 15 years \\
\hline Farm size & $0.85 \mathrm{ha}$ \\
\hline Monthly income & $\mathrm{N} 83,200$ \\
\hline
\end{tabular}

\begin{tabular}{lll} 
Gender & Frequency & $\begin{array}{l}\text { Percentages } \\
\text { Male }\end{array}$ \\
$\begin{array}{l}70 \\
\text { Female }\end{array}$ & 50 & 41.67 \\
Level of Education & & \\
No formal education & 10 & 8.33 \\
Primary education & 60 & 50 \\
Secondary education & 32 & 26.67 \\
Tertiary education & 18 & 15 \\
Memb. Coop. & & \\
& & \\
Yes & 85 & 70.83 \\
$\quad$ No & 35 & 29.17 \\
Sources of capital & & \\
Personal savings & 45 & 37.50 \\
Friends/relatives & 35 & 29.17 \\
Cooperative society & 20 & 16.67 \\
Personal savings + friends & 15 & 12.50 \\
Personal savings + Coop. & 5 & 4.17 \\
\hline Total & $\mathbf{1 2 0}$ & $\mathbf{1 0 0 .}$ \\
\hline
\end{tabular}

From the table, the respondents were at their peak of prosperity showing that the average age of catfish entrepreneurs are middle age group with a mean age of 43 showing people in their active and productive stage of life. This is in agreement with the findings of Nwaru 2004 and okoye 2014 which reports that entrepreneur that are young will be more ready to bear risk and become innovative. 
The household of 7 persons are not so large but means that they can be supportive to fish entrepreurship inorder to reduce labour cost. The mean value of 15 years in catfish production shows a grounded set of entrepreneurs, they have the pre-requiste information which will impact positively on their returns. The table also revealed that more men are involved in fish entrepreneurs may be because of the tediousness or initial cost outlay attached with the business. These could make the female folks to shy away from fish management. The table also showed that the respondents are literate enough to handle the technicalities, information and possible mortality attached to fish production. It equally shows that majority of catfish entrepreneur belong to cooperative which can serve as a cheap source of fund for the business.

Estimation of cost and return of cat fish entrepreneurs in the study area.

Table 2 showing Estimate of cost and return of cat fish entrepreneurs in the study area

\begin{tabular}{|c|c|c|c|}
\hline ITEMS & Price per unit & Value & \% Total Cost \\
\hline \multicolumn{4}{|l|}{ REVENUE: } \\
\hline Sale of cat fish & 4000kg@1168.3 & $4,673,521.25$ & \\
\hline \multicolumn{2}{|l|}{ (A)TOTAL REVENUE } & $4,673,521.25$ & \\
\hline \multicolumn{4}{|l|}{ VARIABLE COST: } \\
\hline Cost of Fish Feed & 300kg@7194.85 & 2158456.00 & 61.49 \\
\hline Cost of Fish fingerlings & 600kg@353 & 211801.00 & 6.03 \\
\hline Cost of Lime/Fertilizer & 50kg@69.46 & 3473.18 & 0.10 \\
\hline Cost of Labour & 10mandays@6929.69 & 69296.88 & 1.97 \\
\hline Cost of Fuel & 100litres@213.1 & 21314.19 & 0.61 \\
\hline Cost of Transport & $17 \mathrm{~km} @ 1882.3$ & 32000.00 & 0.91 \\
\hline Harvest cost & varies@18000.00 & & 0.51 \\
\hline Cost of drugs & 60kg@445 & 26700.00 & 0.76 \\
\hline Cost of detergent & 45litres@711.11 & 32000.00 & 0.91 \\
\hline \multicolumn{2}{|c|}{ (B)TOTAL VARIABLE COST } & 2573041.25 & 73.32 \\
\hline \multicolumn{4}{|l|}{ FIXED COST: } \\
\hline Rent & 0.5Ha@1101232.86 & 550616.43 & 15.69 \\
\hline Depreciation on fixed as & & 386610.15 & 11.01 \\
\hline \multicolumn{2}{|l|}{ (C)TOTAL FIXED COST } & 937226.58 & 26.70 \\
\hline \multicolumn{2}{|c|}{ (D) TOTAL COST $(\mathrm{B}+\mathrm{C})$} & 3510267.83 & 100.00 \\
\hline \multicolumn{2}{|c|}{ NET FARM INCOME (A- D) } & 1163253.42 & \\
\hline
\end{tabular}

Field survey data, 2015

Table 2 revealed the cost and return of cat fish entrepreneurs in the study area. It revealed that the total variable cost was estimated as $\$ 2573041.25$ which is about $73.32 \%$ of the total cost and it also shows that large amount of money spend by cat fish entrepreneur in the study area was majorly for purchase of fish feeds (\$2158456.00) and fingerlings( $\$ 211801.00)$. This finding is in agreement with Louise (1977) who said that the cost of feeds was very high in cat fish production. This is followed by cost of fingerlings while, total fixed cost was 937226.58 which is $26.70 \%$ of the total cost incurred in cat fish production.

The Total fixed cost is comprised of cost of land hired (shadow cost for inherited and/or family land) which was $\$ 550616.43$ (15.69\%) and the depreciation value of fixed assets used in cat fish production activities such as hoe, machetes, shovel, wheel barrow, cost of earthen pond, deep well, concrete tank, water pump, drag 
Determinants of catfish entrepreneurship in Imo state Nigeria.

net and basin was $\$ 3,449.10$ (11.01\%). while total revenue(TR) of $\$ 4,673,521.25$ was realized. This indicates that cat fish production in the study area was profitable. This result is consistent with the finding of Ashaolu $e t$ al. (2006) who sampled fish farmers per cropping season.

Multiple Regression Analysis result on factors influencing the net returns of fish.

Table 3: Multiple Regression Analysis result on Factors Influencing the net returns of fish in Imo State.

\begin{tabular}{|lllll|}
\hline Explanatory & $\begin{array}{l}\text { Linear } \\
\text { Variable }\end{array}$ & $\begin{array}{l}\text { Semi- log } \\
\text { Function }\end{array}$ & $\begin{array}{l}\text { Double- log } \\
\text { Function }\end{array}$ & $\begin{array}{l}\text { Exponential } \\
\text { Function }\end{array}$ \\
\hline Constant & -13389.7 & -4432.8 & 0.1343 & 11.963 \\
(term) & $(-0.28005)$ & $(-2.183)^{* *}$ & $(-1.1430)$ & $(-7.4682)^{* * *}$ \\
Farm size & 289.0 & 713.615 & 4612.8 & 0.00161 \\
$\left(\mathrm{X}_{1}\right)$ & $(1.642)$ & $(13.7218)^{* * *}$ & $(0.981)$ & $(0.9226)$ \\
Cost of labour & 3.32101 & 292.14 & 1.281 & $2.14 \mathrm{E}-05$ \\
$\left(\mathrm{X}_{2}\right)$ & $(1.5308)$ & $(1.601)$ & $(0.181)$ & $(0.2781)$ \\
Household size & 2065.22 & 320.41 & 26131 & 0.00712 \\
$\left(\mathrm{X}_{3}\right)$ & $(0.8451)$ & $(1.9840)^{* *}$ & $(5.123)^{* * *}$ & $(0.08695)$ \\
F. experience & -627.811 & -0.9421 & -227.11 & -0.0081 \\
$\left(\mathrm{X}_{4}\right)$ & $(-0.36115)$ & $(0.14) * * *$ & $(-0.012)$ & $(-0.013893)$ \\
Educational level & 832.46 & 28.142 & 3019.4 & 0.00723 \\
Other input cost & -0.89012 & 401.310 & 2.4198 & 0.000197 \\
$\left(\mathrm{X}_{6}\right)$ & $(-0.0987)$ & $(1.3011)^{* * *}$ & $(2.180)^{* *}$ & $(0.6531)$ \\
Fixed cost & -1.2666 & -2.4198 & -1.901 & $-7.2 \mathrm{E}-07$ \\
$\left(\mathrm{X}_{7}\right)$ & $(-1.4423)$ & $(-3.131)^{* * *}$ & $(-0.012)$ & $(-0.02622)$ \\
Marital status & 4827.17 & 401.81 & 3401.29 & 0.02175 \\
$\left(\mathrm{X}_{9}\right)$ & $90.6325)$ & $(1.2811)$ & $(0.9814)$ & $(0.08508)$ \\
Gender & -19289.6 & -2.1994 & -4.1368 & -0.055 \\
$\left(\mathrm{X}_{10}\right)$ & $(-0.90811)$ & $(-1.1430)$ & $(-1.9920)^{* *}$ & $(-0.1625)$ \\
R- square & 0.8014 & 0.8324 & 0.741 & 0.2411 \\
F- value & 51.241 & 54.122 & 50.31 & 3.4623 \\
\hline
\end{tabular}

Source: Field Survey Data, 2015

The result of the Multiple Regression Analysis on the factors affecting the net return of catfish production is presented in table 3 the semi -log function is selected as the Lead equation based on Magnitude of $\mathrm{R}^{2}$, significance of $\mathrm{F}$ - value and the number of significant variables. The F-ratio value is statistically significant at $1 \%$ which shows the robustness of the estimating model. The co-efficient Of Multiple Determination $\left(\mathrm{R}^{2}\right)$ was $83.24 \%$. This means that the independent variables explain about $83.3 \%$ of the variation in the Net return of Catfish production while the remaining $16.8 \%$ is accounted for by the error term.

The coefficient of farm size, Household size, experience in fish entrepreneurship, fixed cost and were positive and statistically significant, these is consistent with apriori that increase in farm size encourages the building of more ponds which will expand production and increase returns. The coefficient of household size is a two way variable this is because increase in household increases the manpower required in the production of fish, but also can reduce the quantity for sale as family consumption increases. The entrepreneur's experience in fish production and marketing is germane in that it conforms with apriori this is because an increase in farming experience increases yield of fish production and marketing. Fixed cost in an enterprise means land machinery, pond construction etc. It is an important variable because these are expenses that hardly varies and are responsible for generation of wealth. The cost of input such as feed belong to variable cost therefore cost of feed and other inputs when they increase, the returns becomes small and when they decrease the entrepreneur makes huge profit, this is consistent with apriori.

\section{Conclusion}

From the findings of this study, it is observed that

1. Cat fish entrepreneurs are mostly male at their productive age which portrays better future for catfish production.

2. Cat fish entrepreneurship in Imo State is profitable, but faced with problems of inadequate finance, high cost of labour, high cost of transportation, high processing cost, high rate of spoilage and problem of storage. 


\section{Policy Implication}

Favourable policies on land acquisition should be enacted by the government and the necessary machineries be put in place to ensure that fish farmers acquire more land for their farming activities which will in turn increase productivity. Government should provide necessary infrastructural facilities for cat fish farmers in order to reduce the high rate of spoilage and to reduce the high cost of processing. Stakeholders, nongovernmental organization and donor organization should provide small grants as means of funding for cat fish entrepreneurs.

\section{References}

[1]. Adekoya B.B and Muller J.W (2009) Fish cage culture potential in Nigeria - An overview National cultures agriculture focus. 1(5): 10 .

[2]. Amao J.O Awoyeni, T.T Omonona, B.T and Falusi, A.O (2009). Determinants of poverty among fish farming households in Osun State, Nigeria, International Journal of Agricultural Economics in the Rural Development, 2 (2): 14-25.

[3]. Amiengheme P. (2005).The importance of Fish in Human Nutrition. A paper delivered at a Fish culture Forum, Federal Department of Fish Farmers,Abuja.

[4]. Ashaolu, F.O., A.A Akinyemi, and L.S.O Nzekwe 2006 Economic Viability of Cole; 2005. What is Entrepreneurship?

[5]. Esu, et al (2009) Cost and Returns of Fish Production using a Earthen pond in Akwalbom State, Nigeria.

[6]. Food and Agricultural Organization (FAO) (2006a) Nigeria's fisheries profile.

[7]. Hempel, E, (2012) Value Chain Analysis of the Fisheries Sub-sector on Africa. A report carried out in collaboration with INFOSA and funded by the Trade Working Group of the PARTNERSHIP FOR AFRICAN FISHERIES; an AU/NEPAD Programme.

[8]. Presidential Forum on Fisheries and Aquaculture:Status and Opportunities.(2005) Abuja,Nigeria.

[9]. Wiklund, J (1998): Small Firm Growth and Performance: Entrepreneurship and Beyond Doctoral Thesis, Jonkoping International Business School, Sweden Wiley and Sons Inc.

[10]. Osuji, M.N., Ohajianya, D.O., Lemchi, J. I., Eze, C. C.,Henri-Ukoha, A., and Onwuagba, I.J. (2012). Determinants of revenue among Small Holder irrigation Vegetable Farmers in Imo state of Nigeria. International Journal of Agriculture and Rural Development,15(3),1212-1215.

[11]. Okoye B.C (2010). Analysis of Market Participation Among SmallHolder Cassava Farmers In Response To Transportation Costs In South East Nigeria. Unpublished Ph. D-Thesis Agricultural Economics Department, MOUA, Umudike.

[12]. National Population Commission (NPC, (2006). Census Publication.

[13]. Nwaru, J.C. (2004). Rural Credit Markets and Resource Use in Arable Crop Production in Imo State of Nigeria.Unpublished Ph.D Thesis Michael Okpara University of Agriculture, Umudike 